\title{
Early Replication in Pulmonary B Cells After Infection with Marek's Disease Herpesvirus by the Respiratory Route
}

\author{
B.J.G. Baaten, ${ }^{*}$ K.A. Staines, L.P. Smith, H. Skinner, T.F. Davison, and C. Butter
}

\begin{abstract}
Natural infection with Marek's disease virus occurs through the respiratory mucosa after chickens inhale dander shed from infected chickens. The early events in the lung following exposure to the feather and squamous epithelial cell debris containing the viral particles remain unclear. In order to elucidate the virological and immunological consequences of MDV infection for the respiratory tract, chickens were infected by intratracheal administration of infective dander. Differences between susceptible and resistant chickens were immediately apparent, with delayed viral replication and earlier onset of interferon (IFN)-g production in the latter. $\mathrm{CD} 4^{\mathrm{b}}$ and $\mathrm{CD} 8^{\mathrm{p}} \mathrm{T}$ cells surrounded infected cells in the lung. Although viral replication was evident in macrophages, pulmonary B cells were the main target cell type in susceptible chickens following intratracheal infection with MDV. In accordance, depletion of B cells curtailed viremia and substantially affected pathogenesis in susceptible chickens. Together the data described here demonstrate the role of pulmonary B cells as the primary and predominant target cells and their importance for MDV pathogenesis.
\end{abstract}

Introduction

$\mathrm{M}$ arek's disease (MD) is a naturally-occurring lymphomatous disease that afflicts susceptible genotypes icken and other species of poultry (54). The causative agent, Marek's disease virus (MDV), is a strictly cellassociated a-herpesvirus (52) that shares many of its biological properties with g-herpesviruses such as Epstein-Barr virus. Release of infectious cell-free virus from the feather follicle epithelium through shedding of feathers and sloughed skin flakes from infected chickens has been shown to be the mechanism by which MDV is spread $(9,18)$. Natural infection occurs through inhalation of this MDV-infective dander. Viral antigen has been visualized in lung macrophages and the virus has been proposed to be taken up by lung phagocytic cells, which could transport it to the lymphoid tissues where it replicates in B and T lymphocytes (1). Experimental studies with cell-associated virus have been instrumental in characterizing MDV pathogenesis following intra-abdominal infection. The cell-associated virus is first detected in splenic lymphocytes and later in thymocytes and bursal cells, where it causes a lytic infection in lymphocytes from $3 \mathrm{~d}$ after infection (reviewed in 5). B cells have been identified as the primary target cells in these organs, although T cells also become lytically infected (7,17,50). After the initial round of cytolytic infection, MDV latently infects $\mathrm{T}$ lymphocytes, and later CD4 ${ }^{\mathrm{P}} \mathrm{T}$ cells become transformed, giving rise to lymphomas in visceral tissues of susceptible chickens. The virus remains latent in resistant strains. It is probably the latently-infected cells that carry the virus to the skin, where reactivation leads to productive infection in the feather follicle epithelium, completing the infectious cycle (15). Genetics play a crucial role in disease outcome, and as such MHC has been shown to be a major contributor (3). However, despite strong contribution of the MHC haplotype, other genes also contribute to resistance, as exemplified by line 6 and 7 strains that share the

$\mathrm{B}^{2}$ locus (40). The susceptible line 7 chickens develop clinical

MD, and have been shown to amplify the virus to a much higher level $(6,12)$. High levels of MDV particles persist in the feather follicle epithelium of susceptible as well as resistant chickens, and this cell-free virus continues to be shed, and is capable of initiating additional infectious cycles.

Most studies of MDV pathogenesis have involved cell- associated MDV, and cell-free MDV or MD vaccines admin- mistered by a parenteral route. Although these approaches have elucidated the various phases of MD pathogenesis, inadvertently the $y$ exempt crucial events that occurdirectly after natural MDV infection via the respiratory tract, and as a result little is known about this early phase. In the present study, we investigated early events after intratracheal infection to identify infected cells and the factors contributing to early MDV pathogenesis. The infection method used is reliable and allows precisely-timed, measurable dose of native MDV to be de- livered to the natural portal of entry. We show increased and earlier viral replication in the lungs of susceptible line 7 chickens compared to resistant line 6 chickens. IFN-g expression in the lung increased after infection, but was delayed in susceptible chickens. The predominant target cells for viral replication are pulmonary B cells, although macrophages can also become infected later in the response. 
Chickens were obtained from parent flocks of outbred Rhode Island Red (RIR), inbred White Leghorn subline $7_{2}$ (line 7, MD-susceptible), or inbred White Leghorn subline $6_{1}$ (line 6, MD-resistant), and maintained in disease-free conditions at the Institute for Animal Health. The parent flocks were not vaccinated and tested negative for antibodies to a range of poultry pathogens, including MDV, infectious bursal disease virus (IBDV), and chicken infectious anemia virus (CIAV). Their progeny were free of maternal antibodies to MDV. Experimental birds were housed in wire cages in isolation rooms entered through an air lock. Each room was provided with high efficiency particle air (HEPA)-filtered air under positive pressure. The rooms were hosed down daily to prevent the build-up of dander on the floor and walls. Food and water were available a d libitum throughout. All animal procedures were performed in accordance with local ethical regulations, and were approved by the U.K. Home Office. Unless otherwise stated, the chickens were 2 wk. of age when infected with MDV.

\section{Dander isolation for infecting chickens}

Thirty RIR chickens were infected by intra-abdominal injection of 1000 pfu of a very virulent strain of serotype-1 MDV, RB1B (46), from the 11th passage in primary chicken kidney cells. Three weeks after infection, dander was collected from the extract filters of the isolation room. This dander was coarselyfiltered using a household flour sieve followed by 315-mm steel mesh, desiccated overnight and stored in 2-g quantities in sealed tubes below -708C. Control dander was obtained from the extract filters of a similar room housing uninfected RIR chicks and treated in the same way. The same batches of dander were used for all of the experiments.

\section{Experimental design}

Known quantities of a suspension of dander were delivered into the lower trachea by carefully inserting the delivery tube of a PennCentury microaerosilizer ${ }^{\mathrm{TM}}$ (PennCentury, Philadelphia, PA) through the glottis and ins ufflating the dander using 2-3 mL of air. Infected chickens were killed when clinical signs of MD reached a predetermined clinical end-point: unable or reluctant to walk (paretic limbs), dis-interested in food or water, assuming a hunched posture with drooping wings and head, displaying loss of weight, and cloudy partially-closed eyes.

\section{Titration of infective dander}

The minimum infecting dose of the batch of MDV-infective dander needed to induce clinical signs of MD was determined by insufflating a standard amount $(5 \mathrm{mg})$ of dander containing different proportions of the MDV-infective material: $5,2.5,1,0.1,0.01,0.002$, or $0.001 \mathrm{mg}$ dose (n 1/48). Another 8 chickens were treated with $5 \mathrm{mg}$ of the uninfected dander. Blood samples (usually $50 \mathrm{~mL}$ ) were obtained by venipuncture at 3,7,10,14,21,35, 48, and $62 \mathrm{~d}$ post-infection (dpi) to monitor MDV viremia by quantitative PCR, and on some occasions test for antibodies against IBDV and CIAV by ELISA (Index, Westbrook, USA). The chickens were monitored for clinical signs of MD for $63 \mathrm{~d}$, after which the experiment was terminated. At $63 \mathrm{dpi}$ all remaining birds were killed, and liver, heart, and brachial=sciatic nerves were removed and fixed in buffered formaldehyde-saline $(\mathrm{pH} 7.5)$ prior to histological processing and staining with hematoxylin and eosin. Tissue sections were examined and scored blindly for lymphocyte infiltration using the MD lesion scoring system described by Burgess et al. (13).

\section{Early events after natural infection}

Thirty chickens from each of the resistant (line 6) and susceptible (line 7) lines were infected by intratracheal insufflation of $2.5 \mathrm{mg}$ of dander. Thirty age-matched birds from each line were used as controls and given $2.5 \mathrm{mg}$ of noninfective dander by the same route. Spleen and lung samples were collected post mortem from six infected and six uninfected chickens of each line at 1,2,3,4, and 5 dpi. Leukocytes were isolated from the spleen and one of the lungs from each chicken and isolated for analysis by flow cytometry and for DNA=RNA extraction. The remaining lung was removed and prepared for cryosectioning and immunostaining.

\section{Depletion of B cells and cell sorting after natural infection}

Sixty chicks from each of the resistant (line 6) and susceptible (line 7) lines were surgically bursectomized at day 18 of embryonation and allowed to hatch. At $2 \mathrm{wk}$ of age, blood B-cell levels were checked, and only those whose B cells were depleted were infected by intratracheal insufflation of $2.5 \mathrm{mg}$ of dander. In addition, an age-matched control group was infected with $2.5 \mathrm{mg}$ of dander. Blood samples $(50 \mathrm{~mL})$ were collected from the wing veins at 3, 7, 10, 16, 23, and 41 dpi for DNA isolation. At 5 and $20 \mathrm{dpi}$, spleens (n 1/43) were re- moved and single-cell suspensions were stained with CT4-FITC (CD4 cells), AV20-PE (B cells), AV14-AlexaFluor-646 (CD8 cells), and KUL-01-biotin=SA-PerCP (macrophages). Cells were sorted four ways using a MoFlo (Dako Cytomation, Glostrup, Denmark), and RNA was extracted from the individual populations.

\section{Preparation of cell suspensions}

Spleens were extracted and homogenized over cell sieves (Becton Dickinson, Frnaklin Lakes, NJ) and blood was drawn from the jugular vein using a 23-gauge needle. Peripheral blood leukocytes (PBL), lung leukocytes, and spleen leukocytes were purified by density gradient centrifugation using Ficoll-Paque Plus (Amersham Pharmacia Biotech, Little Chalfont, UK). Leukocytes were prepared from the spleens by passing through a 70-mm cell strainer, and lung leukocytes were further purified by enzymatic digestion of the lung. Briefly, lungs were washed in PBS and injected in several places with a 
total of 3-4 mL of enzyme cocktail $(556 \mathrm{mg}=\mathrm{mL}$ DNase I [Boehringer Mannheim, Bracknell, U.K.] and $2.2 \mathrm{mg}=\mathrm{mL}$ collagenase D [Boehringer Mannheim] in HBSS [Sigma, Gillingham, U.K.]). After incubation at 378C for 15 min, the first suspension was discarded. Digestions were repeated until the lung tissue had completely disintegrated and subsequent cell suspensions were transferred to

$10 \mathrm{~mm}$ EDTA in HBSS without calcium. The collected cell suspension was filtered using a 70-mm cell strainer and layered onto Ficoll-Paque Plus.

\section{Quantification of MDV and cytokine transcripts}

The amount of MDV present in the DNA isolated from PBL (DNeasy 96 tissue kit; Qiagen, Crawley, U.K.) was quantified using a real-time quantitative PCR assay (Taqman ${ }^{\text {TM}}$; Applied Biosystems, Foster City, CA) for the MDV Meq gene, essentially as described by Kaiser et al. (33). Meq reaction mixtures included primers and probe to an avian housekeeping gene, ovotransferrin (Ovo), labeled with a second fluorescent dye (VIC ${ }^{\mathrm{TM}}$; Applied Biosystems). Raw data were normalized to a positive control included in every run to exclude plate-to-plate variation (14).

Reverse transcription of isolated RNA (RNeasy 96 tissue kit; Qiagen) was performed using a single-tube singleenzyme system reaction (Taqman EZ RT-PCR Kit; Applied Biosystems), essentially as described by Kaiser et al. (33). RNA was analyzed using primer and probe for cytokine transcripts (24) and viral transcripts (14). All cytokine=MDV reactions were corrected for the amount of cellular RNA by using 28S RNA (housekeeping gene) as described for quantitative PCR reactions.

\section{Isolation and quantification of MDV in dander}

DNA was extracted from $2.5 \mathrm{mg}$ of infective dander and $1000 \mathrm{pfu}$ cell-associated MDV for comparison of viral load. A sample $(2.5 \mathrm{mg})$ of the dander was added to $10 \mathrm{~mL}$ of TE buffer $(1 \mathrm{~mm}$ EDTA, $10 \mathrm{~mm}$ Tris-HCl $[\mathrm{pH} 8.0], 2 \% \mathrm{v}=\mathrm{v}$ nonidet

$\mathrm{P} 40$, and $0.05 \% \mathrm{v}=\mathrm{v}$ Tween-20) and incubated over- night, and after sonication $(3 \times 30 \mathrm{sec}$, Soniprep, London, UK), was digested in proteinase $\mathrm{K}(1 \mathrm{mg}=\mathrm{mL})$ in $1 \%(\mathrm{w}=\mathrm{v}) \mathrm{SDS}$ at

458C for $8 \mathrm{~h}$. The supernatant was aspirated after centrifugation (300 $\mathrm{xg}$ for $5 \mathrm{~min}$ ) and DNA was extracted using a DNeasy tissue kit (Qiagen). Viral DNA was quantified using real-time quantitative PCR assay using the Meq gene.

\section{Fluorescent labeling of cell subsets and flow cytometry}

Immunofluorescent staining of leukocytes for flow cytometry analysis was used to quantify relative changes in lymphocyte subpopulations. All antibodies were diluted 1:200 in PBS-BSA $(0.4 \% \mathrm{w}=\mathrm{v})$-aside $(0.1 \% \mathrm{w}=\mathrm{v})$, and $1 \times 10^{6}$ leukocytes were stained with anti-CD8b-biotin (51), followed by streptavidin-APC (Southern Biotechnology Associates, Birmingham, AL). Following incubation, washing, and blocking with 5\% normal mouse serum, the cells were incubated with directlyconjugated anti-chicken monoclonal antibodies CD4-FITC (19), CD3-PE (20), and CD8a-PerCP (51). In separate tubes, duplicate samples were stained for macrophages (KUL-01) (37), followed by Ig (HPL)-FITC (Southern Biotechnology), and th e n B cells (Bu1-PE) (43). Lymphocyte suspensions were analyzed using a Fascial- bur (Becton-Dickinson) and FCSExpress software version 1.0 (DeNovo Software, Los Angeles, CA).

\section{Immunostaining of tissue sections}

Tissues sections (6 mm) were cut using a cryostat (Leica CM1900; Leica, Bannockburn, IL), air-dried overnight, and fixed in acetone for $10 \mathrm{~min}$. Slides were stored airtight at $-708 \mathrm{C}$ until immunohistochemistry. All antibodies were diluted in $0.4 \%(\mathrm{w}=\mathrm{v})$ BSA-PBS and incubated for $60 \mathrm{~min}$. CD8 $\mathrm{a}^{\mathrm{p}} \mathrm{T}$ cells were labeled (AV14, 1:25) and visualized using the Vectastain Elite ABC kit (Vector Laboratories, Peterborough, U.K.), and the Vector NovaRed substrate kit (Vector Laboratories), according to the manufacturer's instructions. Sections were counterstained with he matoxylin (Gill no. 3; Sigma) and permanently mounted in Clearium (Surgipath, Peterborough, U.K.).

Cryosections for immunofluorescent staining were pre-pared as above. Nonspecific reactivity was blocked by incubation with 5\% (v=v) normal mouse serum for $20 \mathrm{~min}$. Macrophages (KUL-01, 1:30) (37), B cells (Bu1, 1:200) (43), $\mathrm{CD}^{\mathrm{p}}$ cells $(\mathrm{AV} 29,1: 30)$, and $\mathrm{CD}^{\mathrm{p}} \mathrm{a}^{\mathrm{p}} \mathrm{T}$ cells $(\mathrm{AV} 14,1: 25)$ were visualized by Alexa568-conjugated goat anti-mouse IgG H=L ( Molecular Probes, Eugene, OR). Where indicated, sections were double-stained with the viral protein pp38 using Alexa488conjugated BD1 (1:100) (36). Nuclei were stained by incubation with $1.09 \mathrm{mM}$ DAPI (Sigma) for 10 min. Sections were mounted in Vectashield (Vector Laboratories) and analyzed using a confocal microscope (Leica SP2 with 405-, 488-, and 568-nm lasers). Control sections were treated similarly, but were incubated with isotype control antibodies.

\section{Statistical analysis}

Mean lesion scores between multiple groups were com- pared using the Kruskal-Wallis test. Where an overall level of significance was observed, Dunn's test was conducted to determine significance between groups. Mortality data were analyzed by the Kaplan and Meier method. Significance in viral load was analyzed using analysis of variance followed by Tukey's test, where overall significance was observed. Statistical analysis was performed using Graphpad Prism software version 4 (GraphPad Software, San Diego, CA).

\section{Results}

Intratracheal administration of MDV-infective dander to mimic the respiratory infection route 
particles in their natural form. Infective or control dander were obtained from the extract vents of rooms housing chickens either infected with cell-associated RB1B virus or control chickens, respectively. The dander consisted of dried sloughed flakes of skin and fragments of feather barbules, and contained small numbers of micrococci (gram-positive cocci in clusters) and gram-negative lactose-positive and lactose-negative rods (data not shown). Overall there we re no major differences between the two preparations. The presence of viral particles in the infective dander was confirmed by extracting MDV DNA and analysis by real-time PCR (data not shown). Insufflating this material de e p into the trachea
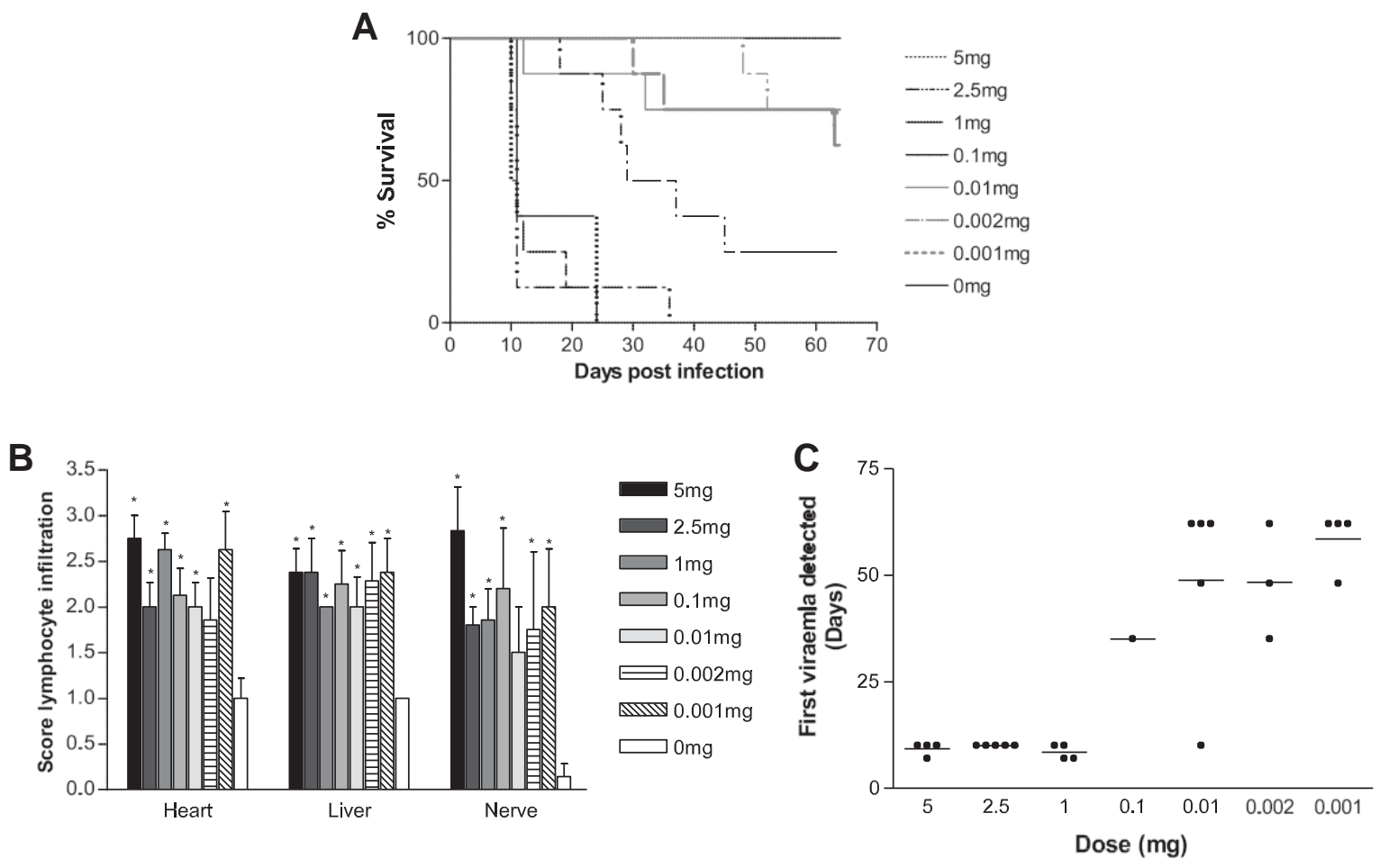

FIG. 1. Natural infection of susceptible line 7 chickens with MDV induces morbidity and pathology in a dose-dependent manner. Natural infection was titrated by intratracheal instillation of 5, 2.5, 1, 0.1, 0.01, 0.002, or 0.001 mg of RB1B-infective dander bulked up to $5 \mathrm{mg}$ with noninfective dander into susceptible line 7 chickens. Controls received $5 \mathrm{mg}$ of noninfective dander. (A) Morbidity and time to reach the defined clinical end-points. (B) Mean lesion scores in heart, liver, and nerve as determined by histological scoring. Values shown are means \pm SEM $(n 1 / 48)(* p<0.05$ difference from uninfected chickens on Kruskal-Wallis test). (C) Detection of MDV levels in PBL as measured by quantitative PCR after infection. Chickens receiving $5 \mathrm{mg}$ of noninfective dander were negative and are not shown. Dots represent individual birds testing positive for virus for the first time, with the horizontal bar representing the mean value.

using a dry-material microaerosolizer appeared to cause only minor interference with respiratory function, and some nonspecific inflammatory changes from which the chicks quickly recovered. Preliminary experiments using a range of doses ( 2.5-20 mg) of MDV-infective dander demonstrated that susceptible RIR chickens developed MD (data not shown). No clinical signs were observed when noninfective dander was administered. After insufflation with either infective or noninfective dander, no clinical or serological manifestation of any other lymphotrophic virus (IBDV or CIAV) in fection was observed. MDV I C P 4 DN A could readily be detected in PBL as early as $5 \mathrm{~d}$ after instillation of 2.5-20 mg of dander.

The initial experiments did not take into account the inflammation caused by the bolus of dander administered and its potential effect on MD pathogenesis. Different doses of MDV-infective dander were tested for their ability to induce MD in susceptible line 7 chickens while standardizing the total administered bolus, and $5 \mathrm{mg}$ of total dander containing different ratios of MDV-infective and noninfective dander was administered to the chickens, which were monitored for clinical signs, MD lesions, and viremia (Fig. 1). More than $50 \%$ of chickens given the higher doses of infective dander

$(1,2.5$, and $5 \mathrm{mg})$ developed clinical signs of $\mathrm{MD}$ by $10-12 \mathrm{dpi}$, whereas these were significantly $(p<0.001)$ delayed in chickens given the lower doses $(0.001,0.002$, and $0.01 \mathrm{mg})$, which survived to the end of the experiment at $63 \mathrm{dpi}$.

Tissues removed post-mortem were examined for the presence of lymphoid lesions by histology. Histology was evaluated at the onset of clinical signs rather than at set time points. All chickens treated with the MDV-infective dander had significantly $(p<0.05)$ greater lymphocyte infiltration into the liver, heart, and nerve post-mortem compared to uninfected birds, but there was no clear evidence that this infiltration was dependent on the treatment dose (Fig. 1B).

MDV levels in PBL were determined by quantitative PCR assay. Viral DNA was not detected in the samples from chickens treated with the noninfective dander (data not shown). The onset of a detectable viremia in infected groups 
was delayed in chickens given smalle r doses of infective dander (Fig. 1C). MDV was detected from 7 dpi onwards in the chickens receiving the higher doses $(5,2.5$, and $1 \mathrm{mg}$ ), but later (from $21 \mathrm{dpi}$ onwards) in chickens receiving the lower doses of MDV-infective dander. In all future experiments

$2.5 \mathrm{mg}$ of infective dander was used for intratracheal infection, as this dose reliably and reproducibly induced MD in susceptible (line 7 and RIR) chickens.

\section{Early viral replication in lung leukocytes of susceptible chickens}

The viral events during the first $5 \mathrm{~d}$ after pulmonary exposure to $2.5 \mathrm{mg} \mathrm{MDV}$-infective or noninfective dander were investigated in chickens

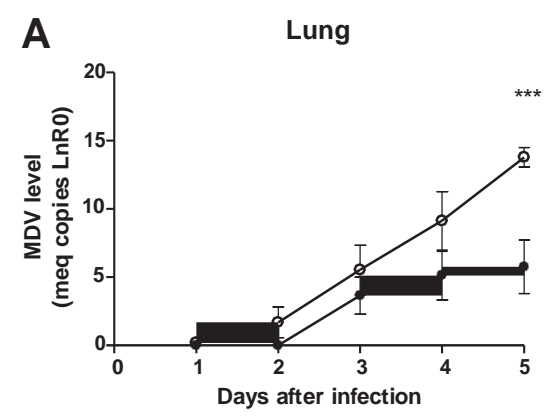
susceptible $\begin{array}{lll}\text { and } & \text { resistant to } \\ \text { Spleen } & \end{array}$

B

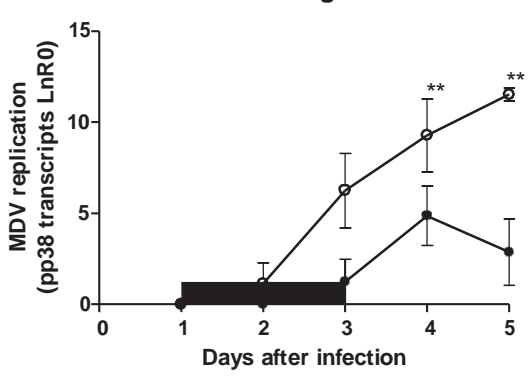

C

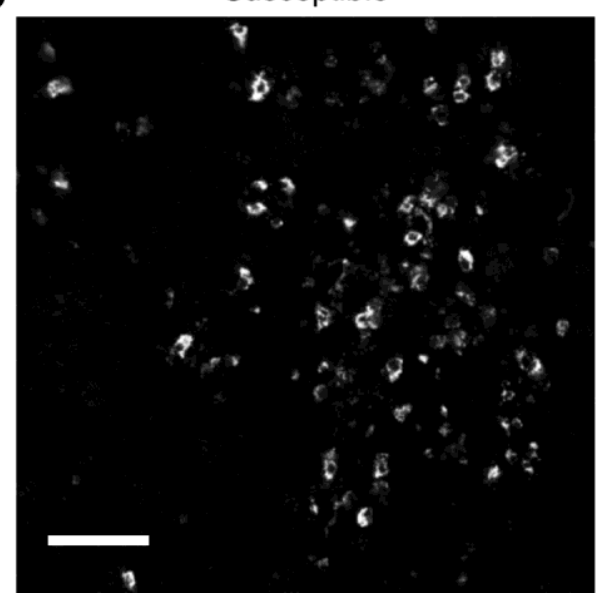

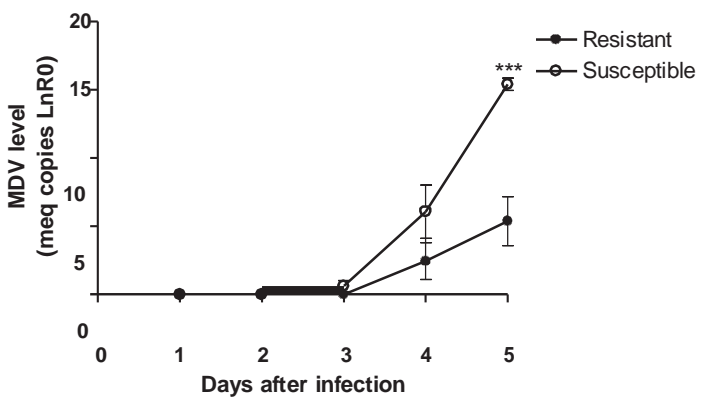

Spleen

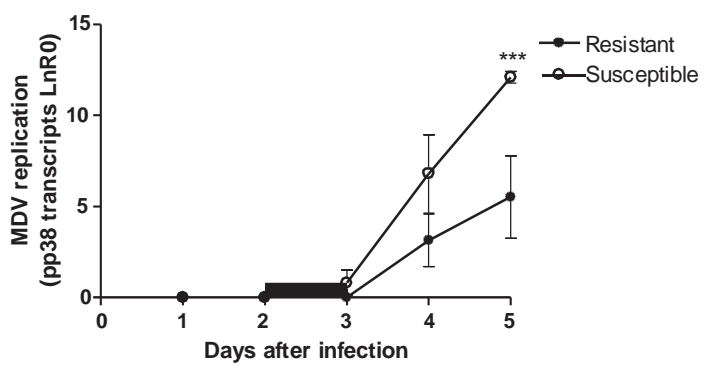

Resistant

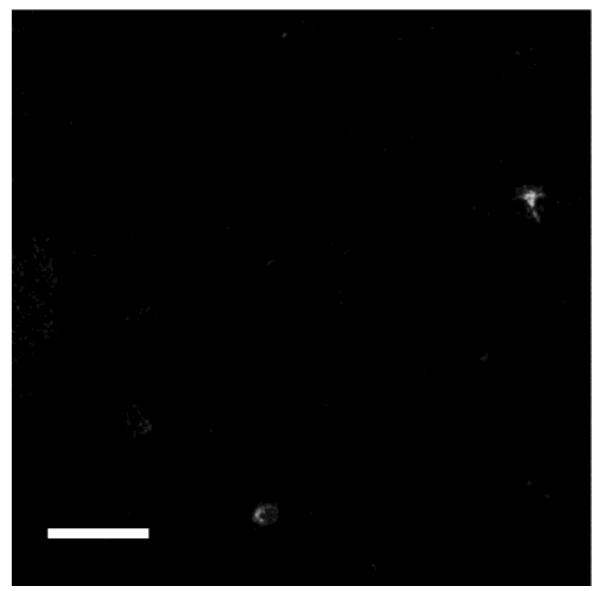

FIG. 2. Early MDV replication in lung and spleen after natural infection. Resistant line 6 and susceptible line 7 chickens were infected by intratracheal instillation of $2.5 \mathrm{mg}$ of RB1B-infective dander and harvested daily for $5 \mathrm{~d}$. DNA and RNA were isolated from lung and spleen leukocytes. (A) Viral load was assessed by the presence of Meq DNA using quantitative PCR. (B) Viral replication in leukocytes was assessed by the expression of RNA transcripts of the early gene, pp38, using quantitative RT-PCR on DNase-treated RNA. Lung leukocytes are shown in the left graph and spleen leukocytes in the right graph. Values shown are means \pm SEM (n 1/4 6). Significance between infected groups: $* * p<0.01 ; * * * p<0.001$. (C) Viral infection in lungs at $5 \mathrm{dpi}$ was visualized by confocal microscopy of sections that were stained for the viral protein pp38, in susceptible (left panel) and resistant (right panel) lungs. (scale bars $1 / 450 \mathrm{~mm}$ ).

MD. DNA was isolated from lung and spleen leukocytes daily after insufflation and tested for the presence of the Meq gene as an indication of the viral load present (Fig. 2A). Viral DNA was detected as early as 2 dpi in lung leukocytes from susceptible chickens, and was delayed by $1 \mathrm{~d}$ in the resistant chickens, and both increased with time. The earliest evidence of MDV in spleen leukocytes was not until a day later in susceptible chickens, at 3 dpi, with a 1-d delay in the leukocytes from 
the resistant chickens.

The presence of MDV genomes was indicative of viral particles, but did not demonstrate viral replication. There-fore, DNase-treated RNA from lung and spleen leukocytes was analyzed by quantitative RT-PCR assay using specific primers and probes for immediate early (ICP4), early (pp38), and late (gB) gene transcripts. Viral RNA (pp38) was first detected in lung leukocytes of susceptible chickens at $2 \mathrm{dpi}$, and of resistant chickens at $3 \mathrm{dpi}$ (Fig. 2B). Similarly to the viral load, detection of pp38 transcripts in spleen leukocytes was delayed by $1 \mathrm{~d}$ compared with the respective values for the lung lymphocytes in both genotypes, which increased with time. From the time of detection, viral replication in the resistant leukocytes remained lower than that in the susceptible leukocytes ( significance at 5 dpi was $\mathrm{p}<0.001$ ). Similar patterns were observed for the GB and ICP 4 transcripts (data not shown).

Viral replication was also evident when lung sections were stained for pp38 antigen using immunofluorescence (Fig. 2C). Five days after infection a substantial amount of viral antigen was present in the lungs of susceptible chickens, but not resistant chickens, confirming the results obtained using RT- PCR.

\section{Inflammatory cytokine transcript levels in lung and spleen leukocytes}

The effect of early viral replication on cytokine levels was assessed, as they could play an important role in MDV Pathogenesis. Transcripts for IFN-a, IFN-b, IFN-g, IL-4, IL-6, IL-18, and TGF-b in lung and splenic leukocytes were measured using quantitative RT-PCR assay. Intratracheal infection with MDV resulted in a substantial and sustained increase in IFN-g transcripts as early as $3 \mathrm{dpi}$ in the lungs of resistant chickens compared to controls, and was delayed in the susceptible chickens (Fig. 3A). No substantial differences based on either genotype or infection could be demonstrated for the other cytokines in lung leukocytes (data not shown). During the first $3 \mathrm{~d}$ after intratracheal infection, there was little effect on the transcript levels of any of the cytokines in spleen leukocytes compared with birds treated with noninfective dander (Fig. 3). However, by $4 \mathrm{dpi}$ there was an in- crease (4-8 times) in the transcript levels of IFN-a, IFN-b, IFN-g, IL-6, and IL-18 in susceptible leukocytes. This increase
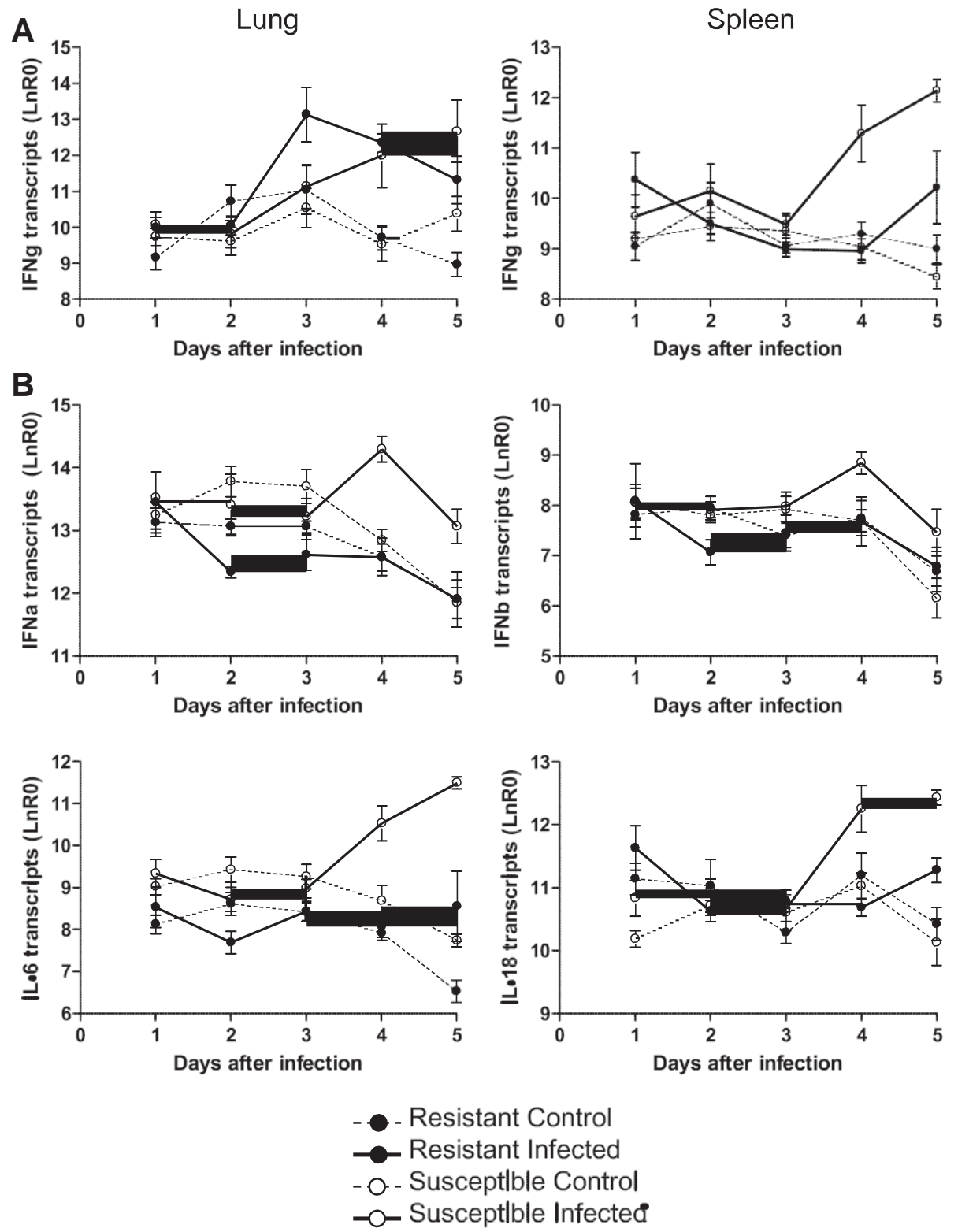
FIG. 3. Cytokine transcript levels in lung and spleen leukocytes of resistant and susceptible birds after intratracheal insufflation with RB1B-infective or control dander. (A) Chicken IFN-g transcripts were measured in RNA extracted from lung leukocytes or spleen leukocytes. (B) IFN-a, IFN-b, IL-6, and IL-18 transcripts in RNA from spleen leukocytes measured using quantitative RT-PCR. All cytokine data were corrected using 28s RNA levels. Values shown are means \pm SEM $\left(n^{1 / 4} 6\right)$.

Was also evident at $5 \mathrm{dpi}$, especially for IFN-g and IL-6, for which a 16-fold increase was observed $(p<0.01$ and $p<0.05$, respectively). In the resistant spleen leukocytes this increase was minimal even at $5 \mathrm{dpi}$, and was restricted to IL-6, IFN-g, and IL-18. The observed increase in spleen leukocytes from susceptible chickens was significantly different (p<0.05) from that of resistant chickens. No differences based on genotype or infection were observed for either IL-4 or TGF-b in the spleen (data not shown). Thus, susceptible chickens seem to have a delay in IFN-g production in the lung and a more profound inflammatory cytokine profile in the spleen.

\section{Increased CD8 T-cell population in the lung after infection}

The effect of intratracheal insufflation of infective dander on proportions and location of lymphoid cells was investigated using flow cytometry. The percentage of $\mathrm{T}$ cells, B cells, and macrophages in the lungs and spleens of resistant and susceptible chickens during early viral replication was determined (Fig. 4). Overall, infection caused a significant in- crease ( $p<0.01$ ) in the ratio of lymphocytes in the lungs of both genotypes from 4 dpi onward, as measured by CD45 expression (data not shown). In the lung, the proportion of $\mathrm{CD}^{\mathrm{b}} \mathrm{CD} 8 \mathrm{ab}{ }^{\mathrm{b}}$ leukocytes increased from 4 dpi after insufflation in the infected compared to uninfected groups to around fourfold at $5 \mathrm{dpi}$ in the susceptible chickens (p<0.05). KUL$01^{\mathrm{b}}$ macrophages displayed a similar profile, increasing to twofold over the uninfected controls by day 5 ( $\left.p<0.05\right)$. Pulmonary $\mathrm{B}$ cells were unaffected in number and remarkably similar between the groups. In the spleen, the percentage of B cells was significantly higher in resistant versus susceptible chickens, with the opposite being demonstrated for T cells. Genotype appeared to affect the cellular

Composition significantly more in the spleen. Other differences were restricted to a reduction in CD8ab $\mathrm{T}^{\mathrm{p}}$ cells at 4 and $5 \mathrm{dpi}$, and $\mathrm{B}$ cells at $5 \mathrm{dpi}$ in the spleens of infected susceptible chickens.

As the predominant change in cellular ratio was observed in lung CD8abp ${ }^{\top}$ cells, the location of these cells following intratracheal infection was investigated using immunohistochemistry (Fig. 5). An increase in the proportion of CD8 $\mathrm{a}^{\mathrm{b}}$ pulmonary leukocytes was evident in both chicken lines following infection. The number of positive cells increased with time, especially in susceptible chickens, in which the CD8 $\mathrm{a}^{\mathrm{b}}$ cells occupied a large proportion of the lung from 3 dpi onward. The CD8 T cells were usually located adjacent to pulmonary spaces.

The spatial relationship between T cells and infected cells was investigated by immunofluorescence. No evidence of infected $\left(\mathrm{pp} 38^{\mathrm{p}}\right)$ CD8 T cells was observed. Even at $5 \mathrm{~d}$ after insufflation no co-localization of the pp38p ${ }^{\text {and }} \mathrm{CD} 8 \mathrm{p}{ }^{\text {cells }}$ could be distinguished (Fig. 5E). However, $\mathrm{CD} 8^{\mathrm{b}} \mathrm{T}$ cells seemed to be surrounding the infected cells. A similar observation was made for $\mathrm{CD}^{\mathrm{P}}{ }^{\mathrm{T}}$ cells (Fig. 5F); after extensive searches no infected cells could be distinguished, even during the highest levels of infection at $5 \mathrm{dpi}$ in susceptible chickens.

\section{Pulmonary B cells are primarily infected following MDV infection}

Although crucial for pathogenesis, the cell types that take up MDV in the lung following natural infection remain unknown. A potential role of macrophages in the uptake and propagation of the virus has been proposed (1, 8). In our experiments, macrophages were predominantly localized around the pulmonary spaces following intratracheal infection (Fig. 6A and B). The potential role of macrophages as carriers of MDV was tested by immunofluorescent double- staining. Viral pp38 antigen was observed in a small percentage of KUL-01 ${ }^{\mathrm{b}}$ macrophages in the lungs of susceptible chickens at 5 dpi, but this was by no means a frequent occurrence (Fig. 6D). Many non-macrophage-infected cells were present and were proposed to be B cells. Double staining of infected cells for the viral antigen pp38 and the B-cell marker Bu1 showed that $\mathrm{B}$ cells were the predominant infected cell type in the lung following infection (Fig. 6E and F). Pp38-Specific staining of the infected cells was predominantly cytoplasmic, near the plasma membrane, and could be detected as early as $3 \mathrm{dpi}$.

The role of B cells in the pathogenesis after natural infection was investigated by depleting all B cells using embryonic surgical bursectomies. Resistant and susceptible chicks were bursectomized at embryonic day 18 before the efflux of B cells into the periphery (reviewed in 53). Control fertilized eggs were set under similar conditions. All chicks were allowed to hatch and were infected by the intratracheal route at $2 \mathrm{wk}$ of age. Bursectomized susceptible line 7 chickens had a similar onset of clinical signs as intact $\mathrm{res}$ istant line 6 chickens (Fig. 7A). The resistant line 6 chickens that had been bursectomized were completely protected from any clinical signs for the duration of the experiment. These data were complemented by reduced viremia in the bursectomized chickens compared to their respective controls (Fig. 7B). In the susceptible line 7 chickens viremia was delayed.

To identify how B cell depletion affected pathogenesis, B cells, macrophages, and CD4 and CD8 T cells were sorted from spleens of chickens infected by the natural route at 5 and $20 \mathrm{dpi}$ (Fig. 7C and D). MDV replication was demonstrated in B cells and macrophages at $5 \mathrm{dpi}$ in susceptible but not resistant chickens, and the cell types had very similar viral loads per cell. No viral replication was observed in T cells at this time point. Depletion of B cells by bursectomy Prevented viral replication in KUL-01 ${ }^{\mathrm{p}}$ macrophages of susceptible chickens. At 20 dpi, predominantly CD4 and CD8 $\mathrm{T}$ cells were infected in the bursectomized susceptible chickens. No intact susceptible line 7 chickens remained for comparison at this time point. Intact resistant chickens showed only very low levels of viral replication in CD4 T cells, but did not have any detectable levels of viral replication once bursectomized. 


\section{Discussion}

MD, a lymphoproliferative disease of chickens, is caused by a virus that is mainly spread by contact exposure. The ability to infect chickens via the respiratory tract has been demonstrated by studies performed as early as the 1970s; infection through contact exposure with airborne suspensions of infective dander $(1,9,15,31,32)$ and with infected individuals $(34,39,48)$, administration of feather tip extracts $(16,21)$, as well as cell-associated virus (38) were all shown to cause MD. However, some characteristics of these approaches, such as reproducibility issues, inability to deliver a quantifiable dose of virus, or delivery 

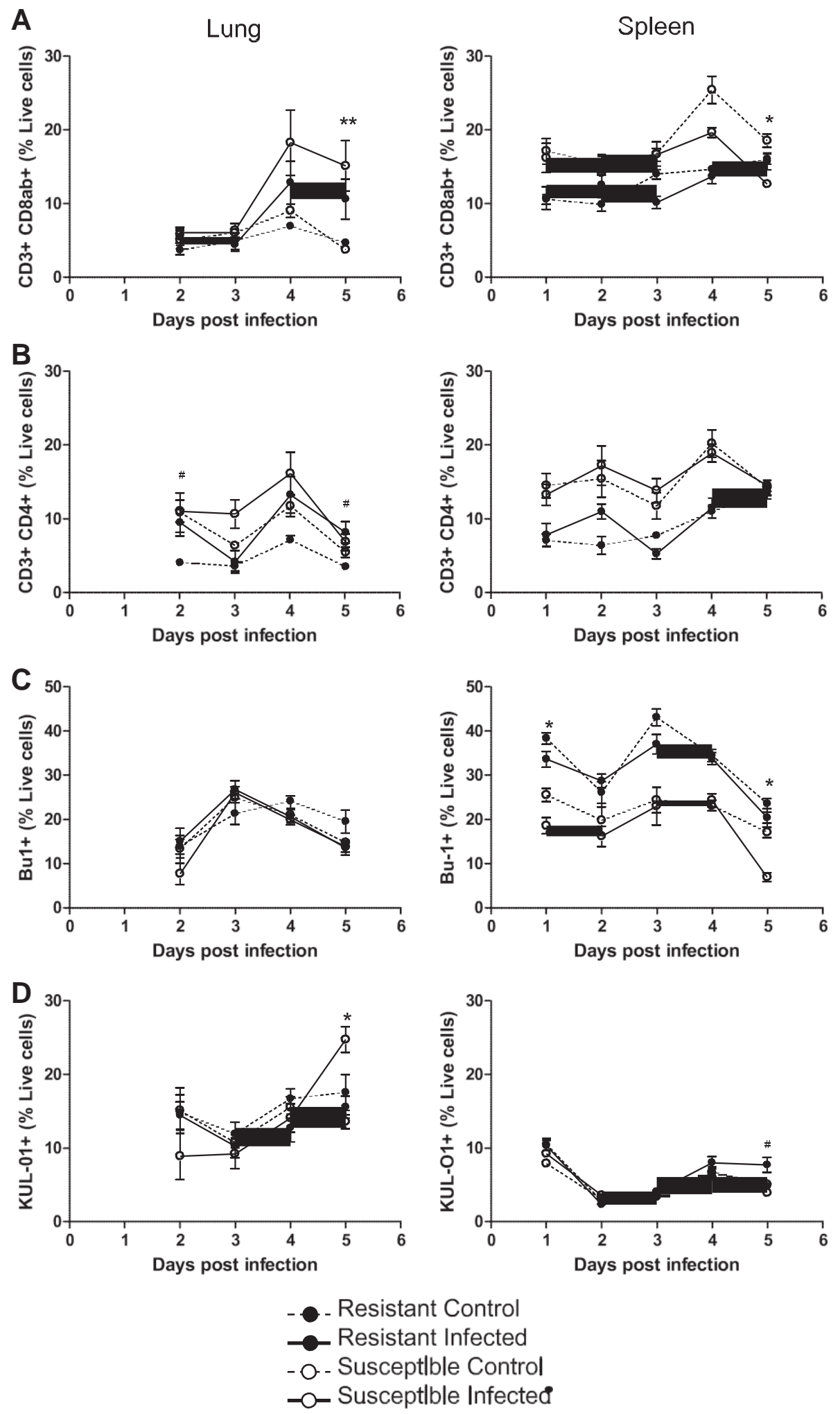

FIG. 4. Early changes in cell populations in the lungs and spleens following pulmonary infection. Single-cell analysis of lung and spleen leukocytes from resistant line 6 and susceptible line 7 chickens following pulmonary exposure to RB1B-infective or noninfective dander. CD8 T cells (A), CD4 T cells (B), B cells (C), or macrophages (D) were identified using flow cytometry and plotted as a ratio of the live cells. Values shown are means \pm SEM (n $1 / 46)$. Significant differences between infected and control chicken is represented as follows: susceptible $* p<0.05, * * p<0.01$, and resistant ${ }^{\#} p<0.05$. 

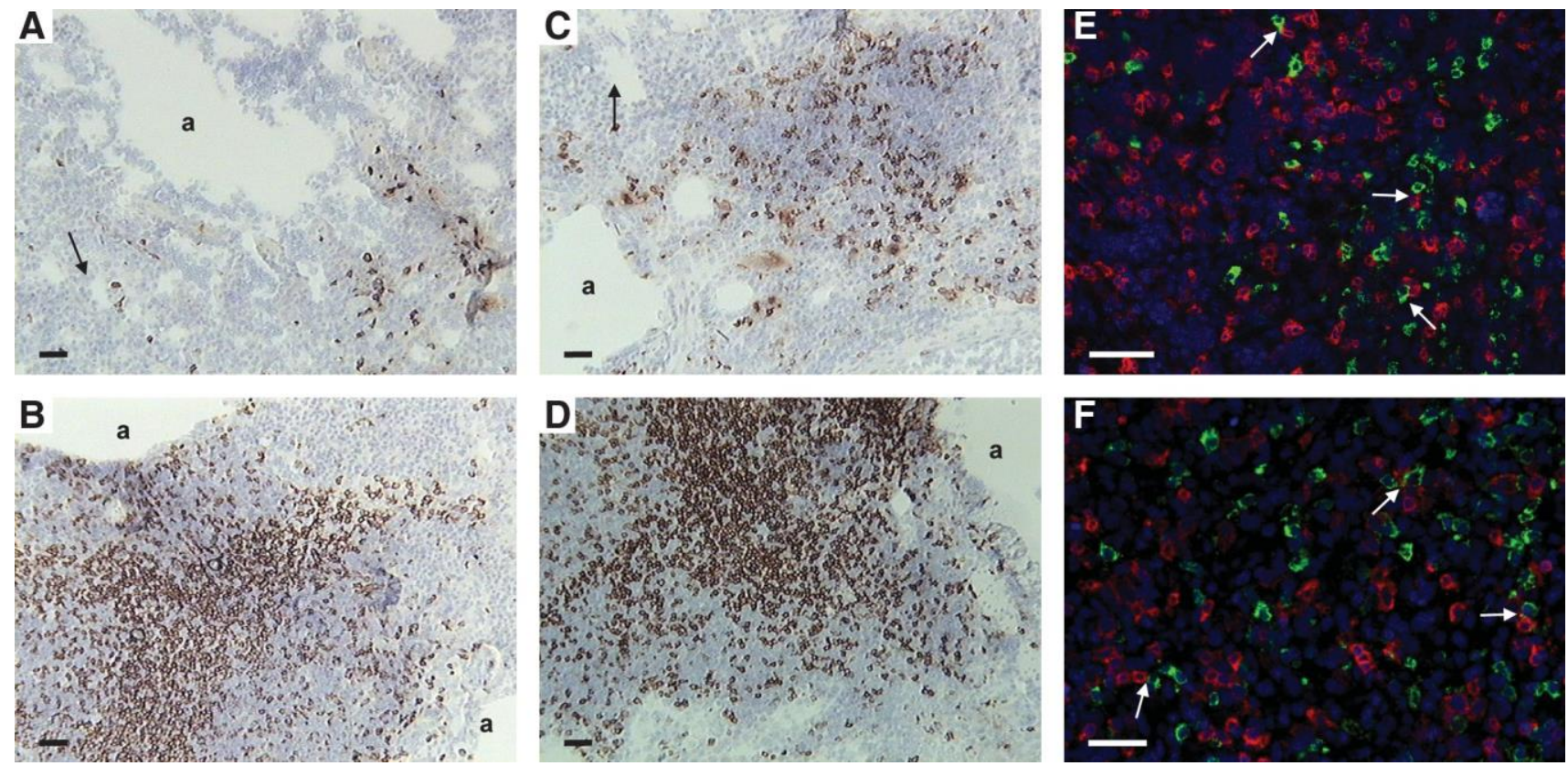

FIG. 5. T-cell populations surround infected cells in the lung after intratracheal infection. Lung sections from resistant (A and $\mathrm{B}$ ) and susceptible (C and $\mathrm{D})$ chickens insufflated with infective (B and $\mathrm{D})$ or control (A and C) dander were immunostained for CD8 antigen $4 \mathrm{~d}$ after insufflation. Some of the parabronchi are indicated by arrows and airways by "a." The relationship of $\mathrm{T}$ cells to infected cells in susceptible lungs was visualized at 5 dpi with immunofluorescent doublestaining by confocal microscopy (E and F). Pp38p-Infected cells (green) are surrounded by CD8 (E) and CD4 T cells (F) (red). White arrows indicate $T$ cells that are in very close proximity to infected cells (scale bars $1 / 450 \mathrm{~mm}$ ).
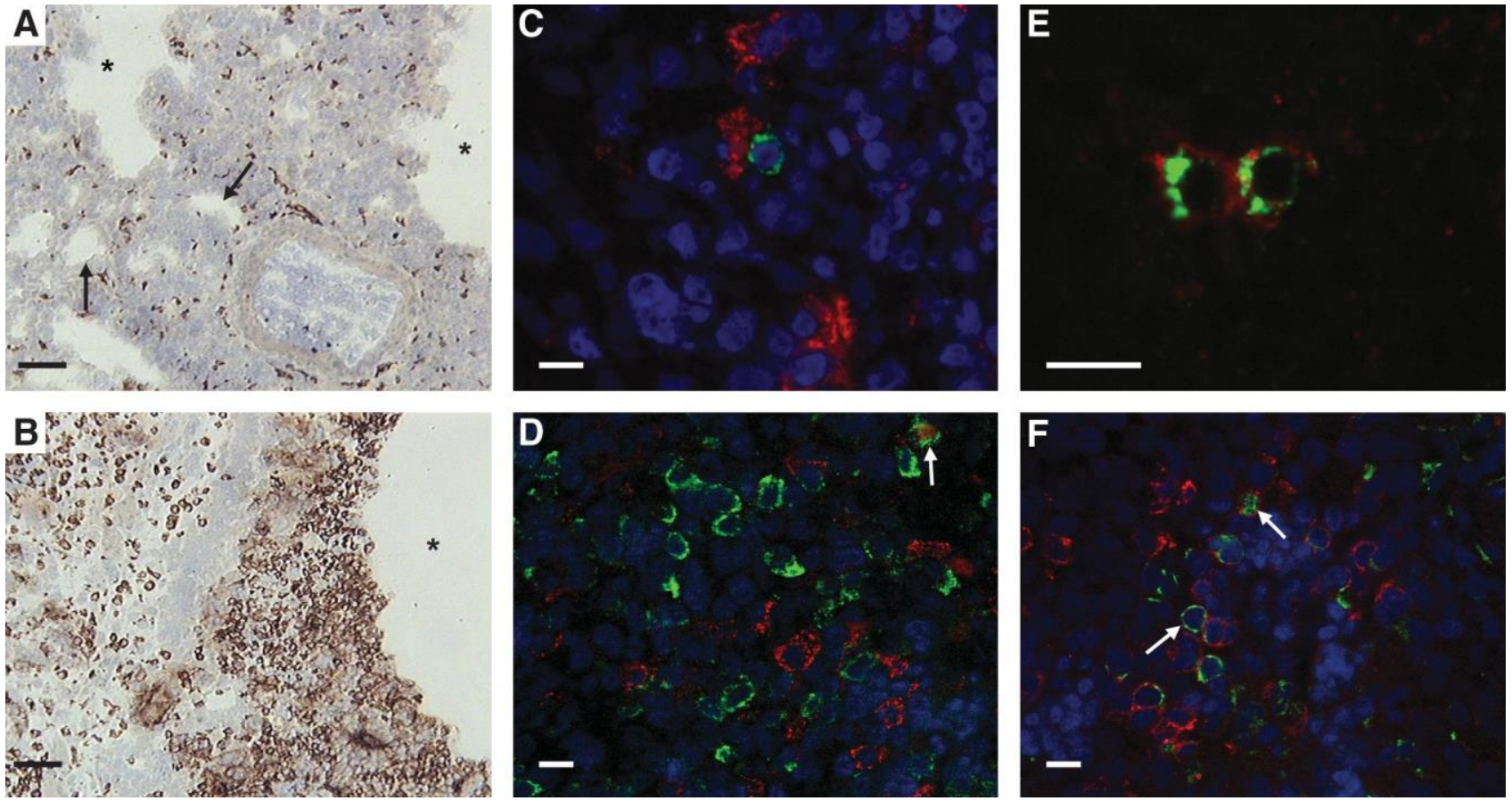

FIG. 6. Viral replication in pulmonary $B$ cells and $m a c r o p h a g e s$ of chickens after infection. The effect of intratracheal infection on macrophages in the lung was assessed by immunohistology. Lungs were removed from control (A) or infected (B) chickens at $1 \mathrm{dpi}$ and stained using KUL-01 antibody. The most intensely stained areas are depicted here. Some of the parabronchi are indicated by arrows, and airways by asterisks ( scale bar $1 / 450 \mathrm{~mm}$ ). B cells, macrophages, and viral pp38 antigen were visualized in lung sections from susceptible line 7 chickens at 3 and 5 dpi by immunofluorescence. Shown are viral pp38 staining (green) co-stained with either macrophage marker KUL-01 (red) (C and D), or B cell marker Bu1 (red) (E and F), at 3 dpi (C and E) and 5 dpi (D and F). Nuclei were visualized with DAPI (blue). White arrows indicate infected cells

(scale

bars

$1 / 4$

10

$\mathrm{mm})$

Tract $(1,9,29)$, precluded their use to investigate early events after infection. The approach to deliver infective dander via the trachea described here circumvents some of these issues, allowing for the exact timing of events following pulmonary infection. The microaerosolizer provides a simple and effective tool to introduce a standard dose of MDV in its native 
form into the trachea in a timed manner. We previously demonstrated the importance of the route and the form of the virus when parenteral infection with cell-associated virus was compared to intratracheal infection with native MDV for resistant and susceptible strains (14). Although $2.5 \mathrm{mg}$ of dander contained 16 times more viral DNA com- pared to 1000 pfu of cell-associated virus (the doses used in the experiments), even increasing the infective dose of cell- associated virus 100 times could not replicate the timing of the clinical signs seen after intratracheal infection (14). In addition, preliminary data suggest that the form of the infective material is also crucial in determining clinical outcome (Staines and Butter, unpublished data). These data highlight the importance of the route of infection for pathogenesis and eventual clinical outcome.

Immune responses in line 6 and 7 genotypes have been investigated by several researchers and were shown to influence the outcome of infection (reviewed in 38). Here, the immune response after natural infection was investigated by quantitative analysis of cytokine transcript levels and cell subpopulations. We show that differences between genetically inbred strains that are susceptible or resistant to MD tumor formation may already be expressed during the early virological events in the pulmonary environment, and could therefore direct the ensuing pathogenesis. Viral replication could be detected as early as 2 dpi in the lung leukocytes of susceptible chickens, whereas that in the spleen was delayed by 1 d. Although cell-associated MDV was reported by Philips and Biggs (41) at $24 \mathrm{~h}$ following natural exposure infection, the length of contact with the infected chickens $(3 \mathrm{~d})$ did not allow for the determination of the precise time of infection (e.g., $24 \mathrm{~h}$ after the end of exposure could actually be $4 \mathrm{~d}$ after initial infection). The 1-d delay for detection of viral replication in the spleen could be a consequence of the transport of the virus from its site of entry. Although it is not clear if transport occurs through blood or lymph, Adldinger and Calnek (1) reported virus in the buffy coat of infected chickens as early as $18 \mathrm{~h}$ after infection. With a limited sensitivity of detection, these authors failed to identify any early replication in the lung. In spleen and lung leukocytes of resistant birds the 1-d delay of detection and significantly reduced viral replication at 5 dpi suggests that resistance is expressed at the replication level at this early stage. A correlation between viral load in the blood and tumor formation in line 6 and 7 chickens has been reported, although this was much later, at 14 dpi (12). That genetic resistance manifests itself so early with respect to viral load is remarkable, and the delay and lower viral load could be a distinct advantage to the resistant line 6, as viral and tumor load are correlated. The reduced viral replication could allow for more time to generate an effective immune response. For example, MDV-induced IFN-g in lung leukocytes of resistant line 6 chickens is concomitant with viral replication, but delayed in those of susceptible chickens. The 2-d delay between viral replication and IFN-g production in lung leukocytes of susceptible birds could provide a crucial time period for the virus to replicate uncontrolled, as IFN-g is a potent inhibitor of MDV replication $(22,56)$. It is unclear what cell population produces the IFN-g in the resistant chickens; the influx of CD8 cells, potent s e cretors of IFN-g, did not occur until 4 dpi. NK cells are a likely candidate and could potentially express IFN-g. The mapping of MD resistance in line 6 and 7 chickens to the MDV1 locus (11), which shows synteny to the Cmv1 locus that controls susceptibility to infection with mouse cytomegalovirus and maps to the mouse NK gene complex (44), suggests a link between genetic resistance and NK cell activity. The importance of NK cells in MD pathogenesis was inferred from genetically resistant chickens that have earlier and stronger NK cell response in resistant $\left(\mathrm{B}^{21} \mathrm{~B}^{21}\right)$ compared to susceptible $\left(\mathrm{B}^{19} \mathrm{~B}^{19}\right)$ chickens $(26,28,49)$. However, these cells were not examined in our experiments.

In the spleen, IFN-g levels correlated with the onset of detectable viral replication and were higher in leukocytes of

susceptible than resistant chickens at 4 and 5 dpi. Temporal expression studies in resistant chickens $\left(\mathrm{B}^{21} \mathrm{~B}^{21}\right)$ have revealed that IFN-g transcription was upregulated in spleen extracts as early as 3 dpi following intra-abdominal infection with cell-associated virus (55). Similar to our data and those of Xing and Schat (55), Kaiser et al. (33) reported strong IFN-g

expression during the first week of viral replication in splenocytes of chickens with the resistant $\mathrm{B}^{21} \mathrm{~B}^{21 \text { or }} \mathrm{B}^{2} \mathrm{~B}^{2}$ haplotype.

However, the delay in IFN-g expression observed in susceptible $\mathrm{B}^{2} \mathrm{~B}^{2}$ or $\mathrm{B}^{19} \mathrm{~B}^{19 \text { chickens }}$ in our experiments was not evident. The viral load between line 6 and 7 splenocytes was also not significantly different in the very first week and at odds with the data reported here. Both could be a result of the infection route. The IFN-g response in the spleen leukocytes corresponded with an overall increase in the levels of IFN-a, IFN-b, IL-6, and IL-18 inflammatory cytokine transcripts 4 and 5 days after intratracheal infection in susceptible birds. Comparable changes for IL-6 and IL-18 transcript levels

between line 6 and 7 chickens have been described (33), although these were later in the in fection. Consistent with earlier hypotheses $(4,35)$, a strong increase in cytokines in the line 7 birds suggests a more profound inflammatory response, which potentially could attract more target lymphocytes. Interestingly, type I IFNs are upregulated in the spleens of susceptible chickens following infection. Hong and Sevoian (30), reported the opposite when using K and S strain

chickens, and although a bioassay was used that could not discern between IFN-a, IFN-b, or IFN-g, overall this was not expected, given the antiviral role of the IFNs.

Overall the differences we observed in the proportions of specific lymphocyte subpopulations in the spleen betwe en the genotypes (more B cells and fewer $\mathrm{T}$ cells in the resistant chickens, independent of infection) were not observed in the lung. Thus a possible role for cell numbers in the lung to affect infection potential and influence genetic resistance, as postulated for the spleen (35), is unlikely. Infection caused an increase in $\mathrm{CD}^{\mathrm{b}} \mathrm{CD} 8 \mathrm{ab}{ }^{\mathrm{b}} \mathrm{T}$ cells in the lungs of both susceptible and resistant chickens while viral replication was increasing. Although cytotoxicity was not addressed in this experiment, a cytotoxic T-cell population capable of lysing MDV-infected target cells is generated following MDV vaccination of line 6 chickens $\left(35,42\right.$ and B.J.G. Baaten, unpublished data). A decrease in the $\mathrm{CD}^{\mathrm{b}} \mathrm{CD} \mathrm{ab}^{\mathrm{p}} \mathrm{T}^{\mathrm{c}-\mathrm{cell}}$
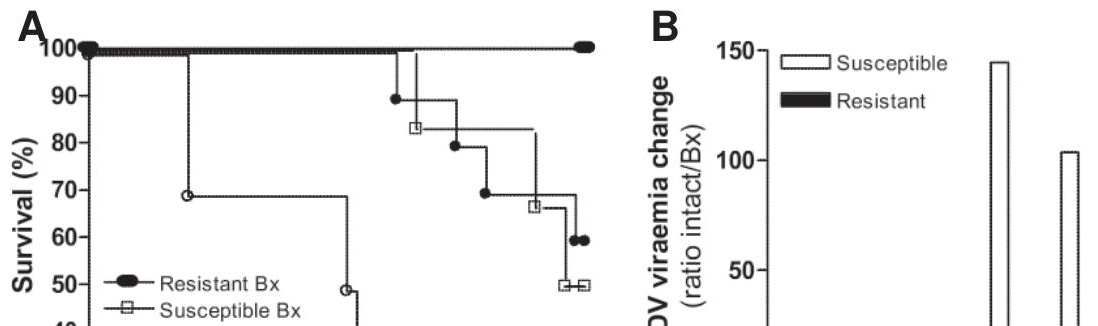
Days after infection

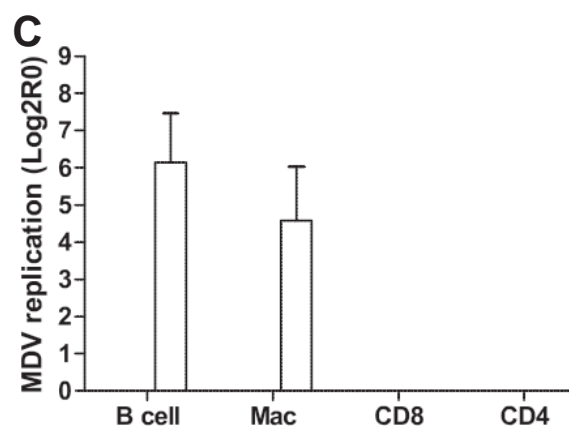

Days after infection

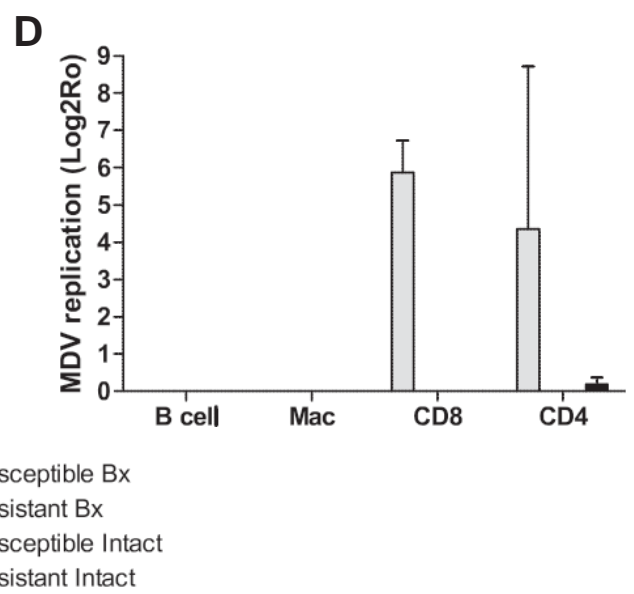

FIG. 7. Depletion of $\mathrm{B}$ cells delays viremia and clinical symptoms after intratracheal infection. Resistant and susceptible chickens bursectomized (Box) at day 18 of embryonation or intact were infected at 2 wk of age. (A) Morbidity and time to reach predefined clinical end-points are shown ( see Materials and Methods section) (Bx n 1/4 6; control n 1/4 10). (B) Changes in viremia over time between intact and Bx chickens were measured by quantitative PCR for the Meq gene and the ratios are graphed here. (C and D) B cells, macrophages (Mac), and CD4 or CD8 T cells were fluorescently sorted and ICP4 RNA transcripts were enumerated in purified populations using quantitative RT-PCR (n $1 / 4$ 3). Viral replication in subpopulations is shown for $5 \mathrm{dpi}(\mathrm{C})$ and $20 \mathrm{dpi}(\mathrm{D})$. The data shown are representative of duplicate experiments.

population in the spleen coincided with extensive viral replication and is most likely a result of cytolytic infection.

We were unable to find infected $\mathrm{T}$ cells in the lung or spleen during the first $5 \mathrm{~d}$. Flowcytometric approaches have shown that as early as $4 \mathrm{~d}$ after intraperitioneal infection $\mathrm{T}$ cells were pp38 $(7)$. The infection route may affect the cell tropism of the infection, and $\mathrm{T}$ cells may not become infected until after the $5 \mathrm{~d}$ investigated in our experiments. It has been postulated that phagocytic cells take up virus particles in the

Lung and transport these to the lymphoid organs, where infection of B and T cells occurs (1). Although infected pulmonary macrophages were identified, there were many KUL-01-negative virus-positive cells present, and thus macrophages were not the predominant infected cell type in the lung. Nevertheless, these do seem to be able to support viral replication, as sorted spleen macrophages from susceptible chickens were positive for MDV mRNA, confirming a report by Barrow et al. (8). However, since we show that a fully productive infection is already in progress in pulmonary B cells as early as $3 \mathrm{~d}$ after infection, when no infected macro- phages can be identified, it seems unlikely that the macro- phages are infected first. Although B cells have been shown to be the primary target cells in spleen following intraperitoneal infection with cellassociated virus, to our knowledge this is the first time that they have been shown to be infected in the lung after respiratory infection. Complete removal of B cells by surgical bursectomy before intratracheal infection greatly impacted pathogenesis, reducing viremia and clinical signs, especially in susceptible line 7 chickens. The substantial impact on pathogenesis is in accordance with results seen following parenteral infection with cell-associated virus (45). Further analysis of the cell types infected revealed that $\mathrm{B}$ cells and macrophages were infected, but that B-cell depletion did not only impact the B-cell compartment, but also prevented viral replication in macrophages of susceptible chickens. The absence of any detectable viral replication in sorted populations from line 6 spleens may be due to a lower level being undetected, and due to the timing of the event. Whereas secondary effects of bursectomy cannot be excluded, these data suggest that infection of B cells is required for macro- phage infection, and provides more evidence for the B cells as the primary targets for MDV. These data confirm and extend earlier suggestions that MDV can replicate in macrophages (8), but challenge the paradigm that the macro- phage's role in the pathogenesis is to transport MDV from the lung to the lymphoid organs, where the cytolytic phase ensues. Apparent differences between resistant and susceptible chickens do not seem to stem from a difference in the number of target B cells, as these were consistent over time. It is more likely that pulmonary B cells from line 7 chickens are more susceptible on a per-cell basis compared to those from resistant chickens, as reported by Lee et al. (35). It is not clear from our data whether B cells become infected directly, as is the case for other lymphotrophic herpesviruses (i.e., Epstein- Barr virus), or through an intermediate cell type, such as lung epithelium. Several researchers $(23,41)$ have demonstrated that chicken lung epithelial cells themselves can harbor MDV antigen. Epithelial cells in the atria and infundibila have been shown to phagocytose small particles that enter parabronchi in other avian species (47). It is possible that epithelial cells become infected while translocating viral particles from the air-side of the lung to the parenchyma. Here, B cells could become infected directly by translocated viral particles, or indirectly through infected epithelial cells. Therefore genotypic variation at this level could account for the difference in viral replication demonstrated, and this is an area of great interest.

A better understanding of the early events following natural infection with MDV is crucial to investigate the possibilities of designing vaccines that block infection (reviewed in 2 and 27). Whereas current vaccineshave been instrumental in controlling disease, they target viral replication. Challenge viruses still infect, replicate in, and are shed by MDvaccinated chickens, providing a reservoir of MDV pathotypes that can survive vaccine-induced immune responses and are 
able to infect other chickens (10). Epidemiological modeling studies predict that vaccines that target pathogen replication tend to drive the pathogen to increased virulence (25). In contrast, vaccines that interfere at the infection stage, before amplification of the pathogen, may have a neutral or even negative effect on the evolution of virulence. Knowledge of the cellular and molecular events in the lung immediately following natural infection will aid in the eradication of the disease.

\section{Conclusion}

The data described here demonstrate that there is extensive viral replication in the lung within the first $5 \mathrm{~d}$ after intratracheal infection of susceptible chickens, which is complemented by an increase in inflammatory cytokines and the arrival of CD8 T cells. These events are delayed by $1 \mathrm{~d}$ in the resistant chickens, although interestingly, there is early increased and sustained IFN-g expression in the lungs. Our findings suggest that pulmonary B cells sustain this early viral replication, whereas only a small number of infected macrophages can be identified.

\section{Acknowledgments}

This work was supported by DEFRA and the BBSRC. The authors would like to thank D r. G.J. Underwood for help and guidance with the animal model, Dr. P. Barrow for bacteriological examination of dander samples, H. Davis for screening serum samples for IBDV and CIAV, Dr. D. Worth and J. Oldham for cell sorting, and Dr. P. Kaiser for generous donation of cytokine primers and probes.

\section{Author Disclosure Statement}

No competing financial interests exist.

\section{References}

1. Adldinger H, and Calnek B: Pathogenesis of Marek's dis- ease: Early distribution of virus and viral antigens in infected chickens. J Natl Cancer Institute 1973; 50:1287-1298.

2. Baaten BJ, Butter C, and Davison TF: Study of host-pathogen interactions to identify sustainable vaccine strategies to Marek's disease. Vet Immunol Immunopathol 2004;100:165-177.

3. Bacon LD, Hunt HD, and Cheng HH: Genetic resistance to Marek's disease. Curr Top Microbiol Immunol 2001;255:121141.

4. Baigent S, and Davison F: Development and composition of lymphoid lesions in the spleens of Marek's disease virusinfected chickens: association with virus spread and the pathogenesis of Marek's disease. Avian Pathol 1999;28:287300 .

5. Baigent S, and Davison F: Marek's disease virus: biology and life cycle. In: Marek's Disease: An Evolving Problem. (Davison F, and Venugopal K, eds.). Elsevier, Oxford, 2004, pp. 62-77.

6. Baigent SJ, Ross LJ, and Davison TF: A flow cytometric method for identifying Marek's disease virus pp38 expression in lymphocyte subpopulations. Avian Pathol $1996 ; 25$ : 255-267.

7. Baigent SJ, Ross LJ, and Davi s on TF: Differential susceptibility to Marek's disease is associated with differences in number, but not phenotype or location, of pp38p lymphocytes. J Gen Virol 1998;79:2795-2802.

8. Barrow AD, Burgess SC, Baigent SJ, Howes K, and Nair VK: Infection of macrophages by a lymphotropic herpesvirus: a new tropism for Marek's disease virus. J Gen Virol 2003;84: 2635-2645.

9. Beasley JN, Patterson LT, and McWade DH: Transmission of Marek's disease by poultry house dust and chicken dander. Am J Vet Res 1970;31:339-344.

10. Bublot M, and Sharma JM: Vaccination against Marek's disease. In: Marek's Disease: An Evolving Problem. (Davison F, and Venugopal K, eds.). Elsevier, Oxford, 2004, pp. 168-185.

11. Bumstead N: Genomic mapping of resistance to Marek's disease. Avian Pathol 1998;27:S78-S81.

12. Bumstead N, Sillibourne J, Rennie M, Ross N, and Davison

F: Quantification of Marek's disease virus in chicken lymphocytes using the polymerase chain reaction with fluorescence detection. J Virol Methods 1997;65:75-81.

13. Burgess SC, Basaran BH, and Davison TF: 2001 Resistance to Marek's disease herpesvirus-induced lymphoma is multi- phasic and dependent on host genotype. Vet Pathol 1997;38: $129-142$.

14. Butter C, Staines K, Baaten B, Smith L, and D a vi s on TF: Route of challenge is critical in determining the clinical out- come of infection with a very virulent oncogenic herpesvirus, Marek's disease virus. Avian Pathol 2007;36:93-99.

15. Calnek BW, Adldinger HK, and Kahn DE: Feather follicle epithelium: a source of enveloped and infectious cell-free herpesvirus from Marek's disease. Avian Dis 1970;14:219233.

16. Calnek BW, Hitchner SB, and Adldinger HK: Lyophilization of cell-free Marek's disease herpes virus and a herpesvirus from turkeys. Appl Microbiol 1970;20:723-726.

17. Calnek BW, Schat KA, Ross LJ, Shek WR, and Chen CL: Further characterization of Marek's disease virus-infected lymphocytes. I. In vivo infection. Int J Cancer 1984;33:389398.

18. Carrozza JH, Fredrickson TN, Prince RP, and Luginbuhl RE: Role of desquamated epithelial cells in transmission of Marek's disease. Avian Dis 1973;17:767-781.

19. Chan MM, Chen CL, Ager LL, and Cooper MD: Identification of the avian homologues of mammalian CD4 and CD8 antigens. J 
Immunol 1988; 140:2133-2138.

20. Chen CL, Ager LL, Gartland GL, and Cooper MD: Identification of a T3=T cell receptor complex in chickens. J Exp Med 1986;164:375-380.

21. Davidson I, and Borenshtain R: Novel applications of feather tip extracts from MDV-infected chickens; diagnosis of commercial broilers, whole genome separation by PFGE and synchronic mucosal infection. FEMS Immunol Med Micro- biol 2003;38:199203.

22. Djeraba A, Bernardet N, Dambrine G, and Quere P: Nitric oxide inhibits Marek's disease virus replication but is not the single decisive factor in interferon-gamma-mediated viral inhibition. Virology 2000;277:58-65.

23. Eidson CS, Giambrone JJ, Fletcher OJ, and Kleven SH:

Vaccination against Marek's disease with cell-free herpes- virus of turkeys by aerosol vaccination. Poultry Science 1980;59:54-62.

24. Eldaghayes I, Rothwell L, Williams A, Withers D, Balu S, Davison F, and Kaiser P: Infectious bursal disease virus: strains that differ in virulence differentially modulate the innate immune response to infection in the chicken bursa. Viral Immunol 2006;19:83-91.

25. Gandon S, Mackinnon MJ, Nee S, and Read AF: Imperfect vaccines and the evolution of pathogen virulence. Nature 2001;414:751-756.

26. Garcia-Camacho L, Schat KA, Brooks Jr R, and Bounous DI: Early cell-mediated immune responses to Marek's disease virus in two chicken lines with defined major histocompatibility complex antigens. Vet Immunol Immunopathol 2003; 95:145-153.

27. Gimeno IM: Marek's disease vaccines: a solution for today but a worry for tomorrow? Vaccine 2008;26(Suppl 3):C31-C41.

28. Heller ED, and Schat KA: Enhancement of natural killer cell activity by Marek's disease vaccines. Avian Pathol 1987;16: 51-60.

29. Higgins DA, and Calnek BW: Some effects of silical treatment on Marek's disease. Infect Immun 1976;13:1054-1060.

30. Hong CC, and Sevoian M: Interferon production and host resistance to type II avian (Marks) le uk os is virus (JMstrain). Appl Microbiol 1971;22:818-820.

31. Islam AF, Walkden-Brown SW, Burgess SK, and Groves PJ: Marek's disease in broiler chickens: effect of route of infection and herpesvirus of turkey-vaccination status on detection of virus from blood or spleen by polymerase chain reaction, and on weights of birds, bursa and spleen. Avian Pathol 2001;30:621-628.

32. Jurajda V, and Klimes B: Presence and survival of Marek's disease agent in dust. Avian Dis 1970; 14:188-190.

33. Kaiser P, Underwood G, and Davison F: Differential cytokine responses following Marek's disease virus infection of chickens differing in resistance to Marek's disease. J Virol 2003;77:762-768.

34. Kenzy SG, and Cho BR: Transmission of classical Marek's dis- ease by affected and carrier birds. Avian Dis 1969;13:211-214.

35. Lee LF, Powell PC, Rennie M, Ross LJ, and Payne LN: Nature of genetic resistance to Marek's disease in chickens. J Natl Cancer Inst 1981;66:789-796.

36. Li D, Green PF, Skinner MA, Jiang C, and Ross N: Use of recombinant pp38 antigen of Marek's disease virus to identify serotype 1-specific antibodies in chicken sera by Western blotting. J Virol Methods 1994;50:185-195.

37. Mast J, Goddeeris BM, Peeters K, Vandesande F, and Berghman LR: Characterisation of chicken monocytes, macrophages and interdigitating cells by the monoclonal antibody KUL01. Vet Immunol Immunopathol 1998;61:343357.

38. Mikami T: Determinants of host resistance to Marek's disease. In: Advances in Marek's Disease Research. (Kato S, Horiuchi T, Mikami T, and Hirai K, eds.). Japanese Association on Marek's Disease, Osaka, pp. 244-253.

39. Okamura H, Sakaguchi M, Yokogawa K, Tokunaga E, Abe S, Tokiyoshi S, and Mizuno K: Lack of contact transmission of recombinant Marek's disease virus type 1 expressing the fusion protein of Newcastle disease virus. Vaccine 2001;20: 483-489.

40. Pazderka F, Longenecker BM, Law GRJ, Stone HA, and Ruth RF: Histocompatibility of chicken populations selected for resistance to Marek's dis e as e. Immunogenetics 1975;2:93-

100.

41. Philips PA, and Biggs PM: Course of infection in tissues of susceptible chickens after expos ure to strains of Marek's disease virus and turkey herpesvirus. J Natl Cancer Institute 1972;49:1367-1373.

42. Ross LJ: Antiviral T cell-mediated immunity in Marek's disease. Nature 1977;268:644-646.

43. Rothwell C J, Vervelde L, and Davison TF: Identification of chicken B u-1 alloantigens using the monoclonal antibody AV20. Vet Immunol Immunopathol 1996;55:225-234.

44. Scalzo AA, Fitzgerald NA, Wallace CR, Gibbons AE, Smart YC, Burton RC, and Shellam GR: The effect of the CMV-1 resistance gene, which is linked to the natural killer cell gene complex, is mediated by natural killer cells. J Immunol 1992;149:581-589.

45. Schat KA, Calnek BW, and Fabricant J: Influence of the bursa of Fabricius on the pathogenesis of Marek's disease. Infect Immun 1981;31:199-207.

46. Schat KA, Calnek BW, and Fabricant J: Characterisation of two highly oncogenic strains of Marek's disease virus. Avian Pathol 1982;11:593-605.

47. Scheuermann DW, Klika E, De Groodt-Lasseel MH, Bazantova I, and Switka A: An electron microscopic study of the parabronchial epithelium in the mature lung of four bird species. Anat Rec 1997;249:213-225.

48. Schmittle SC, and Eidson CS: Studies on acute Marek's disease. IV. Relative susceptibility of different lines and crosses of chickens to GA isolate. Avian Dis 1968;12: 571-576.

49. Sharma JM: Natural killer cell activity in chickens exposed to Marek's disease virus: inhibition of activity in susceptible chickens and enhancement of activity in resistant and vaccinated chickens. Avian Dis 1981;25:882-893.

50. Shek WR, Calnek BW, Schat KA, and Chen CH: Characterization of Marek's disease virus-infected lymphocytes: dis- crimination between cytolytically and latently infected cells. J Natl Cancer Inst 1983;70:485-491. 
51. Tregaskes CA, Kong FK, Paramithiotis E, Chen CL, Ratcliffe MJ, Davison TF, and Young JR: Identification and analysis of the expression of CD8 alpha beta and CD8 alpha alpha isoforms in chickens reveals a major TCR-gamma delta CD8 alpha beta subset of intestinal intraepithelial lymphocytes. J Immunol 1995;154:4485-4494.

52. Van Regenmortel MHV, Fauqet CM, Bishop DHL, et al.: Seventh Report of the International Committee on Taxonomy of Viruses. Academic Press, New York, 1999.

53. Weill JC, and Reynaud CA: The chicken B cell compartment. Science 1987;238:1094-1098.

54. Witter RL, and Schat AK: Marek's disease. In: Diseases of Poultry. (Saif YM, ed.). Iowa State University Press, Aimes, Iowa, 2003, pp. $405-464$.

55. Xing Z, and Schat KA: Expression of cytokine genes in Marek's disease virus-infected chickens and chicken embryo fibroblast cultures. Immunology 2000;100:70-76.

56. Xing Z, and Schat KA: Inhibitory effects of nitric oxide and gamma interferon on in vitro and in vivo replication of Marek's disease virus. J Virol 2000;74:3605-3612.

Address correspondence to:

Dr. B.J.G. Baaten

Burnham Institute for Medical Research 10901 N Torrey Pines Rd.

La Jolla

CA 92037

E-mail: bbaaten@burnham.org

Received May 28, 2009; accepted September 7, 2009. 